\title{
URGENSI KURIKULUM INTEGRASI DI PONDOK PESANTREN DALAM MEMBENTUK MANUSIA BERKUALITAS
}

\author{
Fauzan \\ STAI Al-Khairat Pamekasan \\ masfauzan@gmail.com
}

\begin{abstract}
The isnsitence of globalization and modernization become achallange to education, include pesantren. Globaliation and modernization in one side can advance education it self, but its existence must be responded wisely in order to not bring up negatif impact to the pesantren. Pesantren can respond the globalization and modernization current by innovate pesantren especially in curriculum development. The development of curriculum can be taken by integrate curriculum pesantren with goverment curriculum which is absolut neccesity for the santri to compete in real world in the community. Openning formal education from primary school until university is one of way the executed of integrated curriculum in pesantren. With the integrated curriculum makes santri can tak part in their world in gloabalization and modernization pressure. Curriculum pesantren also can be developed using curriculum based on life skills curriculum which is provide santri ablity in solve poblems in their live and several skills like agriculture, economi, mechanic, domestic industry, and other produktif enterprise.
\end{abstract}

Keywords : globalization, modernization, pesantren, integrated curriculum, life skills.

\begin{abstract}
Abstrak
Derasnya arus globalisasi dan modernisasi menjadi tantangan tersendiri bagi dunia pendidikan, termasuk pesantren. Globalisasi dan modernisasi memang dapat mendonkrak pendidikan ke arah kemajuan, namun kehadirannya perlu disikapi dengan langkah bijak agar tidak berdampak negatif terhadap pesantren.Menyikapi arus globalisasi dan modernisasi dapat dilakukan dengan inovasi pesantren terutama pengembangan kurikulumnya. Pengembangan kurikulum dapat dilakukan dengan mengintegrasikan kurikulum pesantren dengan kurikulum umum atau pemerintah yang mutlak menjadi kebutuhan santri untuk bersaing di dunia nyata di masyrakat. Dengan dibukanya lembaga pendidikan formal di pesantren mulai dari tingkat sekolah dasar hingga perguruan tinggi merupakan contoh terlaksananya integrasi kurikulum di pesantren. Dengan kurikulum integrasi menjadikan santri mampu berkiprah di tengah kerasnya arus globalisasi dan modernisasi.Kurikulum pesantren juga dapat dikembangkan dengan menggunakan kurikulum berbasis kecakapan hidup (life skills), dimana santri dibekali dengan kemampuan dalam memecahkan berbagai masalah hidup dan keterampilan-keterampilan tertentu seperti pertanian,
\end{abstract}


pengembangan ekonomi, elektronik, montir, industri rumah tangga, dan usaha produktif lainnya.

Kata kunci : globalisasi, modernisasi, pesantren, kurikulum integrasi, kecakapan hidup.

\section{Pendahuluan}

Tidak dapat terbantahkan bahwa pendidikan perannya amat penting dalam kehidupan manusia, karena pendidikan dapat membawa manusia ke arah kedewasaan, kemandirian dan perubahan dalam hidupnya. Sistem pendidikan yang telah berkembang seperti sekarang merupakan metamorfosis dari pendidikan pesantren yang telah lama tumbuh dan berkembang di Indonesia.

Tumbuh dan berkembangnya pendidikan di Indonesia berasal dari berkembangnya pesantren yang telah ada, bahkan sejak sebelum Indonesia merdeka. Pesantren sebagai lembaga pendidikan Islam memiliki pengaruh besar dalam pengembangan sumber daya manusia di Indonesia khususnya di bidang pendidikan. ${ }^{1}$ Keberadaan pesantren juga berperan besar dalam pembentukan karakter bangsa Indonesia. Eksistensinya dari masa ke masa telah memberikan kontribusi konkrit dalam perjalanan sejarah bangsa.

Seiring dengan perubahan zaman, pesantren juga mengalami perkembangan dari masa ke masa. Perubahan itu sebagai respon atas tuntutan zaman yang semakin hari kian menunjukan adanya percepatan perubahan yang membutuhkan balance dari semua pergerakan termasuk pesantren. Sudah banyak pesantren yang mengembangkan pendidikannya dengan mendirikan madrasah dan sekolah.

Pesantren dikelola dengan sistem tradisional, sedangkan madrasah dan sekolah dikelola dengan sistem konvensional. Eksistensi madrasah dan sekolah di merupakan langkah strategis pihak pesantren dalam memperbaiki sistem pendidikannya. Kehadiran madrasah dan sekolah tidak lantas menggusur sistem pendidikan di pesantren yang tradisional, melainkan justru melengkapinya. Madrasah dan sekolah dikelola dengan sistem modern menggunakan kurikulum dan senantiasa memperhatikan perubahan strategis dalam merespon modernitas.

Persentuhan pesantren dengan dunia modern dapat merubah stigma masyarakat terhadap pesantren dari pesantren salaf menjadi pesantren modern. Sebut saja Pesantren Gontor yang menampilkan dirinya sebagai pesantren modern yang dikelola secara sistematiss. Pesantren modern biasanya menjadikan bahasa asing seperti bahasa Arab dan Inggris sebagai

\footnotetext{
${ }^{1}$ Moh. Mahfud dan Artamin Hairit, "Pondok Pesantren Masa Depan (Studi Pola Manajemen PP. Nahdlatun Nasyiin Bungbaruh Kadur Pamekasan)", Jurnal Fikrotuna, Volume 4, Nomor 2 (Lembaga Penelitian dan Pengabdian Masyarakat, Desember, 2016), 1
} 
Fauzan, Urgensi Kurikulum Integrasi di Pondok Pesantren dalam Membentuk Manusia Berkualitas

bahasa pengantar sehari-hari. Sedangkan pesantren salaf penekannya lebih kepada penguasaan kitab-kitab klasik sebagai bekal dakwah yang menjadi tujuan awal dibentuknya pesantren. Berbeda dengan pesantren salaf, pesantren modern memiliki sistem, metode, dan kurikulum yang lebih tertata. Sistem seperti itu diciptakan sebagai respon atas tuntutan modernisasi.

Arus modernitas yang tak terbendung lagi, menjadi tantangan tersendiri bagi pesantren. Perkembangan zaman yang sedemikian cepatnya harus direspon dengan cepat pula dengan pendekatan multidisipliner. Pesantren tidak lagi cukup hanya dengan membekali santri dengan kemampuan dasar-dasar ilmu agama yang bersumber dari kitab-kitab klasik. Santri perlu dibekali dengan pelbagai kemampuan disiplin ilmu yang relevan dengan perubahan zaman tersebut. Refitalisasi ini dimaksudkan untuk menghasilkan out put pesantren yang tangguh, berpengetahuan luas dengan kekuaatan jiwa pesantren, dan keteguhan mempertahankan dan mengembangkan pengetahuan yang bersumber pada al-Qur'an dan Hadits.

Dengan integrasi pengetahuan yang diperoleh di pesantren, menjadikan santri memiliki kompetensi yang siap berkiprah di masyarakat dengan multi potensinya dan sanggup berkompetisi dengan arus globalisasi dan modernisasi.

\section{Dinamika Pesantren}

Pesantren atau yang biasa disebut dengan pondok pesantren merupakan lembaga keagamaan, yang melaksanana pendidikan dan pengajaran serta mengembangkan dan menyebarkan ilmu agama dan Islam. Kehadiran pesantren di tanah air memberikan investasi terhadap lahirnya pendidikan, karena dari kajian historis pendidikan di Indonesia, pesantren merupakan cikal bakal lahirnya pendidikan di Indonesia. Sebelum ada pendidikan formal di Indonesia, pesantren sudah ada dan berkembang di Indonesia. Makanya tidak salah kalau dikatakan pesantren sebagai warisan pendidikan Indonesia dan memiliki peran yang besar dalam pembangunan bangsa.

Pesantren merupakan salah satu warisan pendidikan Islam tertua dan asli Indonesia (indigenous) yang memiliki peran sangat penting dalam pembangunan bangsa. Sejak awal berdirinya, pesantren selalu terlibat dalam persoalan-persoalan kebangsaan, melalui kepemimpinan para ulama/kyai yang memiliki kekuatan spiritual, iman yang teguh, keikhlasan berjuang, dan ketangguhan moral, pesantren-pesantren yang tersebar di pedesaanpedesaan telah berperan besar dalam menjaga keutuhan bangsa Indonesia dari upaya 
pemecah-belahan penjajah. Pada masa perjuangan kemerdekaan misalnya para pemimpin Pondok Pesantren dengan jiwa kesantriannya turut ambil bagian dalam bela negara ${ }^{2}$

Mujammil Qomar menyatakan bahwa pada mulanya pesantren didirikan oleh para penyebar Islam sehingga kehadirannya diyakini mengiringi dakwah Islam di negeri ini. Pesantren sejak awal berdirinya hingga saat ini telah mengalami banyak perkembangan. Pada masa awal berdirinya, fungsi pesantren sebagai pusat penyelenggaraan pendidikan dan penyiaran agama Islam. Kedua fungsi ini berjalan dan bergerak saling menunjang. Pendidikan dapat dijadikan bekal dalam mengimplementasikan nilai dakwah sedang dakwah dapat dijadikan sebagai sarana dalam membangun sistem pendidikan. ${ }^{3}$

Pada masa awal berdirinya, pesantren yang satu dengan lainnya memiliki tingkatan yang berbeda-beda. Pesantren yang paling sederhana hanya mengajarkan membaca huruf Arab dan Al-Qur'an. Pesantren yang lebih tinggi mengajarkan berbagai kitab seperti fiqh, aqidah, tauhid, tata bahasa Arab seperti Nahwu dan Sharf, juga amalan sufi, dan lainnya.

Baru pada era 1970-an pesantren mengalami perubahan yang cukup signifikan. Perubahan itu dapat dilihat dari dua hal. Pertama, pesantren mengalami perkembangan kuantitas. Data Departemen Agama menyebutkan pada 1977 jumlah pesantren masih sekitar 4.195 buah dengan jumlah santri sekitar 677.394 orang. Pada tahun 1985 pesantren meningkat menjadi sekitar 6.239 dengan jumlah santri sekitar 1.084.801 orang. Pada 1997 jumlah pesantren sekitar 9.388 dengan jumlah santri sekitar 1.770.768. Pada tahun 2001 jumlah pesantren sekitar 11.312 dengan jumlah santri sekitar 2.737 .805 orang. Periodesasi perkembangan pesantren di atas menunjukkan perubahan yang sangat signifikan.

Perkembangan kedua berkaitan dengan sistem penyelenggaraan pendidikan. Sejak tahun 1970 sistem pendidikan yang diselenggarkan di pesantren sudah mulai bervariasi. M Sulthon dan Moh. Khusnuridlo, menyatakan bahwa bentuk pendidikan pesantren dapat diklasifikasan menjadi empat tipe, yaitu: (a) pesantren yang menyelenggarakan pendidikan formal dengan menerapkan kurikulum nasional, baik yang memiliki sekolah keagamaan seperti MI, MTs, MA, dan PT Agama Islam, maupun yang memiliki sekolah umum seperti SD, SMP, SMA, dan PT Umum, seperti Pesantren Tebuireng Jombang dan pesantren Syafi'iyah Jakarta; (b) pesantren yang menyelenggarakan pendidikan keagamaan dalam

\footnotetext{
${ }^{2}$ Hariyanto dan Minhaji, "Total Quality Management Berbasis Pesantren (Kajian Perspektif Pengelolaan Pendidikan Pesantren)", Fikrouna, Volume 4, Nomor 2 (Lembaga Penelitian dan Pengabdian Masyarakat, Desember, 2016), 1

${ }^{3}$ Mujammil Qomar, Pesantren: dari Transformasi Metodologi menuju Demokratisasi Institusi (Jakarta: Erlangga, 2005), 22
} 
bentuk madrasah dan mengajarkan ilmu agama dan ilmu umum meskipun tidak menerapkan kurikulum nasional, seperti Pesantren Gontor Ponorogo, Daru Rahman Jakrta, Pesantren AlAmin Prenduan Sumenap Madura ; (c) pesantren yang hanya mengajarkan ilmu-ilmu agama saja dengan mendirikan Madrasah Diniyah (MD) seperti Pesantren Lirboyo Kediri dan Pesantren Tegalrejo Magelang; dan (d) pesantren yang hanya sekedar dijadikan tempat pengajian. $^{4}$

\section{Tipologi Pesantren}

Secara umum keberadaan pesantren di Indonesia memiliki ciri-ciri yang hampir sama yaitu untuk mencetak para ulama' atau para ahli dalam agama Islam, walau dalam realitasnya terdapat beberapa perbedaan mendasar terutama dilihat dari proses dan substansi yang diajarkan. Perbedaan yang mendasar pada pesantren dapat dilihat dari tipologinya.

Tipologi pesantren dapat dilihat dari perbedaan yang digunakan pesantren dalam menerapkan metode pembelajaran yang berbeda-beda sesuai dengan kekhasannya. Tipologi pesantren secara garis besar dapat dikelompokkan menjadi 2 kelompok yaitu pesantren salafi (tradisional) dan khalafi (modern). Pesantren salafi adalah pesantren yang tetap mempertahankan pengajaran kitab-kitab Islam klasik sebagai inti dari sistem pendidikan di pesantren. Pesantren khalafi adalah pesantren yang telah mengkombinasikan pengajaran kitab klasik dan pelajaran umum dalam bentuk madrasah yang dikembangkan dalam sekolah baik sekolah agama maupun sekolah umum.

Berbeda dengan tipologi pesantren di atas, Departemen Agama (sekarang Kementerian Agama) membagi tipologi menjadi 3 yaitu pesantren salafiyah, pesantren khalafiyah, dan pesantren campuran/kombinasi. ${ }^{5}$

Pesantren salafiyah adalah pesantren yang menggunakan pendekatan tradisional dalam menyelenggarakan pembelajaran, sebagaimana yang berlangsung sejak awal pertumbuhannya. Sistem pembelajarannya dilakukan secara tradisional pula yaitu sorogan (individual) dan bandongan (kelompok) yang berkonsentrasi pada pengajaran kitab-kitab klasik berbahasa Arab. Sistem perjenjangan tidak didasarkan pada satuan waktu, tetapi berdasarkan pada tamatnya kitab tertentu yang dipelajari. Setelah menamatkan suatu kitab, santri dapat melanjutkan kitab yang tingkat kesukarannya lebih tinggi seperti setelah menamatkan kitab ajurumiyah dapat melanjutkan kitab alfiyah.

\footnotetext{
4 M. Sulthon dan Moh. Khusnuridlo, Manajemen Pondok Pesantren dalam Perspektif Global, (Yogyakarta:LaksBang PRESSindo, 2006), 6-8

5 Departemen Agama RI-Direktorat Jenderal Kelembagaan Agama Islam, Pondok Pesantren dan Madrasah Diniyah: Pertumbuhan dan Perkembangannya, (Jakarta: Depag RI, 2003), 29-31.
} 
Pesantren salafiyah orientasinya pada penguasaan kitab-kitab klasik saja, sehingga menjadi masalah tersendiri bagi lulusan jenis pesantren ini karena tidak bisa melanjutkan ke jenjang yang lain atau memasuki dunia kompetisi yang mensyaratkan sertifikat atau ijazah. Namun demikian namun demikian pesantren salafiyah telah memperoleh penyetaraan melalui SKB 2 Menteri (Menag dan Mendiknas) No : 1/U/KB/2000 dan No. MA/86/2000, tertanggal 30 Maret 2000 yang memberi kesempatan kepada pesantren salafiyah untuk menyelenggarakan pendidikan dasar sebagai upaya mempercepat pelaksanaan program wajib belajar dengan syarat adanya tambahan mata pelajaran Bahasa Indonesia, Matematika, dan IPA dalam kurikulumnya. Adanya SKB ini memberikan implikasi yang sangat besar bagi persantren salaf untuk mempertahankan eksistensi pendidikan pesantren. ${ }^{6}$

KH. Hasan Hasanai Nawawi, Penasehat Majelis Keluarga Pondok Pesantren Sidogiri menyebutkan bahwa pesantren dibentuk agar melahirkan santri yang bertakwa kepada Allah. Artinya pesantren dibangun atas fondasi ketakwaan, dan ditujukan untuk membentuk pribadipribadi yang bertakwa yang semata-mata untuk menjunjung tinggi agama-Nya (li i'la' $i$ kalimatillah). Pesantren dikelola secara intens dalam rangka membentuk pribadi-pribadi yang bertakwa kepada Allah dan mengikuti petunjuk Nabi Muhammad, yang berpedoman kepada al-Qur'an dan Hadits, serta mengikuti jejak langkah ulama salaf saleh, guna membangun peradaban Islam yang tinggi. Maka pesantren, sejak asas dan pondasi, visi-misi, proses pendidikan, hingga target yang dicanangkan benar-benar seiring dengan prinsip-prinsip Islam sebagaimana tuntunan al-Qur' an dan Hadits ${ }^{7}$. Dengan demikian, hasil yang akan dicapai juga akan sesuai dengan rancang-bangun yang telah terkonsep dalam Islam melahirkan manusia seutuhnya dan umat yang terbaik yang dilahrikan untuk manusia, sebagaimana ditegaskan dalam al-Qur'an berikut:

$$
\text { كنتم خير أمة أخرحت للناس تأمرون بالمعروف وتنهون عن المنكر وتؤمنون بالله (ال عمران ) }
$$

Artinya, Kalian adalah umat terbaik yang dilahirkan untuk manusia, menyuruh kepada yang makruf, dan mencegah dari yang mungkar, dan beriman kepada Allah. (QS Al Imran 110).

Pesantren khalafiyah adalah pesantren yang menggunakan pendekatan modern melalui satuan pendidikan formal baik sekolah agama seperti MI, MTs, dan MA maupun sekolah umum seperti SD, SMP, SMA, dan SMK atau nama lainnya. Sistem pembelajaran pada jenis

\footnotetext{
${ }^{6}$ M. Sulthon Masyhud, dkk. Manajemen Pondok Pesantren, (Jakarta: Diva Pustaka, Cet. II, 2004),7

${ }^{7}$ Tim Penulis Pustaka Sidogiri, Mengapa Saya Harus Mondok di Pesantren?, (Pasuran Pustaka Sidogiri, 1431 H) 184-186.
} 
pesantren ini berbeda dengan sistem pembelajaran pesantren salaf, karena pada pesantren ini dilakukan secara berjenjang dan berkesinambungan, dengan satuan program didasarkan pada satuan waktu, seperti semester dan tahun/kelas.

Pesantren campuran salafiyah dan khalafiyah yaitu pesantren yang memadukan sistem salaf dan khalaf. Artinya dalam jenis pesantren ini kajian-kajian kitab klasik yang tidak berjenjang tetap dilaksanakan sebagai sistem orsinel pesantren, dan juga menggunakan sistem modern dengan didirikannya pendidikan formal. Biasanya pesantren semacam ini membagi waktu belajarnya ke dalam dua bagian yaitu pada siang hari belajar di pendidikan formal dan malam belajar kitab klasik.

Tipologi pesantren yang telah berkembang di tengah-tengah masyarakat, tentunya melahirkan orietasi yang berbeda-beda dalam membentuk karakter lulusannya. Hal ini disebabkan disamping karena sistem dan metode yang berbeda, terdapat kekurangan dan kelebihan dalam penyelenggaraannya. Berikut akan diuraikan masing-masing kekurangan dan kelebihan pesantren salaf dan khalaf. Diantara kekurangan pesantren salaf antara lain: (1) Tidak peduli terhadap perubahan zaman, dan kuranga merespon adanya modernisasi. (2) Proses pengajarannya lebih menekankan ilmu fiqh, tasawuf dan ilmu alat. (3) Kualitas dan kuantitas pesantren salaf relatif menjurun. (4) Metode pembelajaran yang digunakan masih bersifat tradisional seperti sorogan, bandungan (halaqah), dan wetonan. (4) Kurangnya penekanan kepada aspek pentingnya membaca dan menulis. (5) Peran kyai sangat dominan sebagai sumber utama dalam pembelajaran

Selain berbagai kelemahan pesantren salaf, pesantren model ini memiliki kelebihan yang bisa dijadikan modal pengembangan. Pertama, Kentalnya Ketakdziman seorang santri terhadap kyai. Kedua, Disamping mumpuni terhadap kajian-kajian agama seperti ilmu fiqh, tasawuf ataupun ilmu alat, juga mampu mencetak kader-kader islam yang berakhlakul karimah. Ketiga, Sebagai pusat tempat belajar ilmu agama. Keempat, Sistem pendidikan yang tidak mengenal strata sosial. Kelima, Mengajarkan semangat kehidupan demokrasi, bekerja sama, persaudaraan, persamaan, percaya diri dan keberanian hidup.

Adapun kekurangan pesantren khalaf antara lain; Pertama, Berkurangya ketakdziman santri kepada kyai, karena santri lebih patuh pada peraturan pesantren. Kedua, Peraturan yang ketat menyebabkan ketidaknyamanan santri dalam belajar. Ketiga, Kurang intensifnya pengajaran ilmu-ilmu agama. Keempat, Adanya kecenderungan santri yang semakin kuat untuk mempelajari IPTEK. Kelima, Menurunnya tradisi mendapatkan barokah dari kyai. 
Perubahan manajmen dan orientasi pesantren khalaf menjadikan pesantren lebib peka terhadap berbagai tuntutan zaman, sehingga pesantren khalaf memiliki beberapa kelebihan sebagai modal pengembangan pesantren. Adapun kelebihan pesantren khalaf antara lain; pertama, sistem, metode serta kurikulum pengajarannya mengikuti perkembangan zaman. Kedua, relatif terbuka untuk menerima perubahan zaman. Ketiga, sistem pengajarannya tidak terbatas kepada penguasaan kitab-kitab klasik saja, tetapi mengembangkan pengetahuan umum yang menjadi kebutuhan santri. Keempat, didirikan pendidikan formal mulai dari sekolah dasar hingga perguruan tinggi baik yang berbasis agama maupun umum di lingkungan pesantren. Kelima, Adanya perubahan terhadap orientasi out putnya yang tidak hanya menjadi guru ngaji atau guru agama, tetapi merambah ke berbagai sektor seperti dunia politik, ekonomi, dan lainnya.

\section{Pesantren dan Tuntutan Perubahan Zaman}

Tantangan yang dihadapi pesantren pada masa awal berkembangnya dengan zaman sekarang tentunya jauh berbeda. Hal ini disebabkan oleh tuntutan keadaan yang jauh berbeda. Perubahan zaman juga dapat merubah visi, misi, dan tujuan pesantren berbeda. Kalau pada zaman dulu pesantren digunakan sebagai media dakwah saja karena yang dihadapi pesantren waktu itu masyarakat yang buta agama dan penjajah belanda, tetapi kondisi saat itu berbeda karena leading sector nya mencakup pelbagai aspek kehidupan manusia, misalnya ekonomi, budaya, politik, dan sebagainya.

Imron Arifin dalam bukunya Kepemimpinan Kyai: Kasus Pondok Pesantren Tebuireng, menyatakan bahwa pada masa awal pertumbuhannya, fungsi pesantren cenderung menjadi alat islamisasi, yang memadukan tiga unsur pendidikan yaitu ibadah untuk menanamkan iman, tabligh untuk menyebarkan ilmu dan amal, dan untuk mewujudkan kegiatan kemasyarakatan dalam kehidupan sehari-hari. ${ }^{8}$

Ruang gerak pesantren pada masa dulu lebih fokus pada bidang dakwah karena memang medan yang dihadapi masyarakat yang buta agama dan penjajah. Pesantren belum bersentuhan dengan sistem masyarakat industri dan arus globalisasi, sehingga pesantren juga dikelola secara tradisional.

Sementara itu, dengan terjadinya pergeseran pradigma masyarakat yang terus berkembang dan berubah, dimana persinggungan antar tradisi dan budaya yang tidak dapat

${ }^{8}$ Imron Arifin, Kepemimpinan Kyai: Kasus Pondok Pesantren Tebuireng, Malang (Kalimasahada Press:1993), 17 
dihindari dan dampak globalisasi yang kian tak terbendung, maka tradisi pesantren tidak mungkin dapat terus bertahan dengan cara dan sistem yang lama. Dalam situasi seperti itu, pesantren dituntut melakukan pembaharuan dan inovasi.

Perubahan zaman seperti ini sejatinya tidak boleh dianggap sebagai penghalang kemajuan pesantren, tetapi perubahan itu harus dianggap sebagai tantangan yang memberikan ruang tersendiri untuk maju. Inovasi akan berjalan berjalan secara lebih maksimal karena adanya tantangan. Pesantren mesti melakukan inovasi pendidikan agar peserta didik (santri) memiliki kompetensi yang mumpuni dalam menghadapi perubahan zaman tersebut. Karena itu, pesantren dituntut melakukan perubahan sistem pendidikannya dengan catatan tidak sampai merubah visi, misi dan orientasi pesantren itu, akan tetapi perubahan tersebut tetap berpegang teguh pada prinsip dasar yaitu

$$
\text { المحافظة على القديم الصالح والاخد بالجديد لاصلح }
$$

Artinya, Melestarikan budaya yang kuno dan mengambil terobosan baru

Senada dengan pendapat di atas, Afiful Khair mengatakan bahwa pesantren sebagai lembaga pendidikan non formal harus mengadakan perubahan dan pembaharuan agar menghasilkan generasi yang tangguh dan berpengetahuan luas dengan kekuatan jiwa pesantren serta memiliki keteguhan untuk mengembangkan pengetahuan yang bersumber pada al-qur'an dan hadis. Pesantren saat ini dihadapkan dengan arus globalisasi dan modernisasi yang ditandai dengan cepatnya laju informasi dan teknologi. Karena itu, pesantren harus melakukan perubahan format, bentuk, orientasi dan metode pendidikan dengan catatan tidak sampai merubah visi, misi dan orientasi pesantren itu, akan tetapi perubahan tersebut hanya pada sisi luarnya saja, sementara pada sisi dalam masih tetap dipertahankan. Eksistensi pondok pesantren dalam menyikapi perkembangan zaman, tentunya memiliki komitmen untuk tetap menyuguhkan pola pendidikan yang mampu melahirkan SDM yang handal. ${ }^{9}$

Berkaitan dengan hal tersebut, Mulyasa mengatakan bahwa peserta didik (santri) harus dibekali dengan berbagai kemampuan yang mampu menjawab tuntutan zaman dan reformasi yang sedang bergulir, guna menjawab tantangan globalisasi, berkontribusi pada

\footnotetext{
${ }^{9}$ Moh. Afiful Hair, "Manajemen Pembaharuan Pesantren di Tengah Tantangan Kehidupan Masarakat Global", Jurnal Fikrotuna, Volume 4, Nomor 2 (Lembaga Penelitian dan Pengabdian Masyarakat, Desember, 2016 ), 2
} 
pembangunan masyarakat dan kesejahteraan sosial, lentur, dan adaptif terhadap berbagai perubahan. $^{10}$

\section{Pentingnya Kurikulum Integrasi di Pesantren}

Adanya tipologi pesantren sebagaimana dijelaskan di atas memunculkan orientasi lulusan pesantren yang berbeda-beda pula. Pesantren salaf misalnya berorientasi melahirkan lulusan yang mempunyai kompetensi dalam ilmu agama dengan bekal kitab-kitab klasik yang tujuan utamanya untuk berdakwah. Adapun pesantren khalaf orientasinya lebih condong melahirkan lulusan yang siap terjun berkompetisi di dunia modern. Sementara lulusan pesantren campuran salaf dan khalaf melahirkan lulusan yang memiliki kompetensi agama dan ilmu umum yang memiliki kematangan untuk berdakwah dan berkompetisi di dunia modern

Format pesantren yang mengkombinasikan sistem salaf dan khalaf merupkan bentuk ideal pesantren kalau melihat hiruk pikuknya dunia yang makin kompetitif. Hal ini dapat dilihat dari berbagai fenomena yang terjadi di masyarakat dari lulusan pesantren yang kembali ke lingkungannya masing-masing. Lulusan pesantren salaf misalnya mendapatkan masalah ketika berhadapan dengan kompetisi dengan dunia kerja, dimana biasanya syarat yang diperlukan bukti kelulusan dan pengalaman kerja. Walaupun sudah ada SKB dua menteri (Menag dan Mendiknas) yang memberikan kesempatan kepada pesantren salaf untuk menyelenggarakan pendidikan dasar, pada kenyataannya tidak semua pesantren salaf membukan diri untuk menyelenggarakan pendidikan dasar sebagaimana harapan diterbitkannya SKB dua menteri tersebut.

Pesantren salaf ansih memang di satu sisi memiliki kelebihan kemampuan kompentensi kitab-kitab klasik, karena selama santri belajar di pesantren rentetan aktifitas pendidikannya hanya berkutat di kajian-kajia kitab klasik. Kyai meyakini bahwa tujuan santri dididik semata-mata untuk mempersiapkan diri mereka dalam menjalani kehidupan masingmasing dalam mendekatkan diri kepada Allah dan untuk mempersiapkan diri menghadapi kehidupan akhirat kelak, sehingga merasa tabu terhadap dunia modern dan global karena dunia modern dan global dianggap dapat mencerabuti intensitas dan ketulusan dalam ibadah manusia.

\footnotetext{
${ }^{10}$ Mulyasa. E, Manajemen Berbasis Sekolah- Konsep, Strategi, dan Implementasi, Bandung (PT Remaja Rosda Karya:2002), vi
} 
Fauzan, Urgensi Kurikulum Integrasi di Pondok Pesantren dalam Membentuk Manusia Berkualitas

Pesantren semacam ini lambat laun akan termarjinalkan karena kerasnya arus modernisasi yang menuntut lulusan pesantren memiliki kemampuan untuk berkiprah di dunia modern dengan kompetensinya yang siap berkreasi di semua sektor kehidupan masyarakat. Kerasnya

Zamakhsyari Dofier menyatakan bahwa kyai sebagai arsitek kemasyarakatan (social engineer) harus memperthatikan selera masyarkat. Dengan memperhatikan selera masyarakat inilah, pesantren mampu bertahan untuk mengembangkan lembaga-lembaga pesantren disesuaikan dengan kehidupan modern. ${ }^{11}$ Artinya bahwa pesantren harus mampu menghadapi tuntutan perubahan zaman yang tidak terbatas sebagai akibat dari kuatnya arus modernitas. Maka pesantren tidak boleh tidak harus mampu mencetak santri sebagai kader bangsa yang hanya berkutat dalam kemampuan bidang kitab kuning saja, tetapi mesti memiliki kemampuan yang relevan dengan tuntutan perubahan zaman. Atas dasar inilah, maka pesantren harus melakukan terobosan baru dengan melakukan perubahan sistemnya dengan mengintegrasikan kurikulum baru dengan tujuan untuk mengimbangi kecerdasan spritual dan kecerdasan intelektual sehingga setelah santri lulus dari pesantren, mereka siap untuk berkompetisi di tengah masyarakat. Sistem integrasi di pesantren dapat dilakukan dengan inovasi kurikulum misalnya mendirikan pendidikan formal mulai dari tingkat dasar hingga tingkat perguruan tinggi.

Eksistensi pesantren dapat dilihat dari kurikulumnya yang mampu memenuhi harapan masyarakat dengan sistem pendidikannya yang berkualitas. Kurikulum dalam disiplin ilmu pendidikan, meliputi tiga aspek materi yaitu: ilmu pengetahuan (kognitif), keterampilan (psikomotorik) dan sikap dan nilai (afektif). Ketiga materi inilah yang membentuk materi pendidikan yang berbentuk disiplin ilmu pengetahuan. Ilmu pengetahuan dapat bersumber dari wahyu ataupun hasil pemikiran manusia. Dalam prakteknya,seharusnya antara ilmu pengetahuan yang berdasarkan wahyu dengan pemikiran akal tidak bertentangan. Justru keduanya dapat diintegrasikan menjadi isi materi kurikulum. Pengintegrasiani ni dilakukan atas dasar beberapa alasan: pertama, diharap kandengan integrasi kurikulum tersebut akan melahirkan output yang mempunyai pengamatan yang terintegritas dengan realitas, artinya inti pengetahuan adalah kebenaran atas realitas yang memberi kebahagiaan di dunia dan akhirat. Kedua, integrasi kurikulum dapat menghasilkan manusia yang memiliki kepribadian yang terpadu pula (integrated personality). Ketiga, diharapkan melalui kandungan kurikulum

${ }^{11}$ Zamakhsyari Dhofier, Tradisi Pesantren- Studi Pandangan Kyai dan visinya Mengenai Masa Depan Pesantren, Jakarta (LP3ES, 2015), 77 
yang terintegrasi antara pengetahuan umum dengan pengetahuan agama akan menimbulkan perpaduan di kalangan masyarakat, berhubungan secara secara harmonis. ${ }^{12}$

Tiga ranah pendidikan yang meliputi ranah kognitif, psikomotorik, dan afektif mutlak diperlukan santri. Oleh karenanya fungsi pesantren tidak hanya dijadikan sebagai tempat menimba ilmu saja, tetapi pesantren juga dapat menjadi lumbung yang berkualitas. Inilah yang menjadi nilai positif pesantren.

Pesantren sebagai bagian dari pendidikan dinilai memiliki kelebihan dibandingkan pendidikan lainnya karena alasan berikut; pertama, Penyelengaraan pendidikan pondok pesantren dengan sistem asrama memungkinkan santri untuk belajar disiplin, menjalin kebersamaan, tenggang rasa, toleransi, kemandirian, dan kesederhanaan. Kedua, Belajar di pesantren selain memperoleh pendidikan agama dan budi pekerti, juga memperoleh pendidikan umum, meskipun prosentasenya lebih rendah dibandingkan sekolah-sekolah umum. Ketiga, Di pesantren diajarkan keterampilan sebagai bekal hidup mandiri, meski belum tentu sesuai dengan kebutuhan masyarakat, menjadikan santri mandiri dan siap kembali ke lingkungannya masing-masing. Keempat, Sistem yang dikembangkan pondok pesantren lebih memungkinkan para santri berkompetisi secara realistis, bukan saja dalam prestasi belajar tetapi juga prestasi dalam berusaha dan bekerja. Pengembangan sikap egalitarian dikalangan para santri merupakan ciri dan kelebihan pondok pesantren. Kelima, Pondok pesantren menciptakan ikatan persaudaraan yang kuat di antara para santri tanpa adanya paksaan, menjadi modal dasar terpenting dalam membangun masyarakat madani. Keenam, Sistem pesantren memungkinkan timbulnya semangat belajar tanpa henti dikalangan para santri, yang belajar dengan sadar bagi perbaikan dirinya. Mereka belajar agar mampu mengatasi persoalan-persoalan hidupnya. ${ }^{13}$

Dengan integrasi kurikulum ini, diharapkan pesantren mampu melahirkan santri yang berkualitas yang mampu berkiprah di dunia global yang sesuai dengan kebutuhan pada masa sekarang dan masa yang akan datang dan dapat mengikuti tuntutan perubahan zaman dengan tidak merusak akidah dan akhlak mulai, sehingga selamat dan sejahtera di dunia maupun di akhirat.

\footnotetext{
${ }^{12}$ Hasan Langgulung, Manusia dan Pendidikan, (Jakarta: Pustaka Al-Husna,1986),195.

${ }^{13}$ Pusat Bahasa Al-Azhar, "Life Skill untuk Meningkatkan Mutu Pendidikan Pesantren Sebagai Bagian dari Usaha Pengembangan Sumber Daya Manusia di Kabupaten Bangkalan, dalam https:// pusatbahasaalazhar. wordpress.com (15 September 2017)
} 
Fauzan, Urgensi Kurikulum Integrasi di Pondok Pesantren dalam Membentuk Manusia Berkualitas

Dengan demikian,diharapkan mampu melahirkan manusia muslim yangberkualitas dan mampu hidup dalam persaingan yang ketat yangdapat mengikuti tuntutan dan perubahan zaman dengan tidakmerusak akidah dan akhlaq mulia, sehingga selamat dansejahtera di dunia maupun di akhirat

\section{Format Pesantren Masa Depan}

Realitas perubahan zaman yang begitu cepat menuntut pesantren untuk melek terhadap arus perubahan yang begitu cepat dan tak terbendung. Integrasi kurikulum merupakan satu solusi yang tidak bisa ditawar lagi. Globalisasi yang menjadi corong perubahan itu harus diimbangi dengan sistem pesantren dalam inovasi pendidikannya. Harapan masyarakat yang begitu besar terhadap pesantren agar mampu melahirkan generasi yang memiliki kompetensi unggul tidak dapat diabaikan.

Menurut Zamakhsyari Dofier, pada dasawarsa 1998-2008 tradisi pesantren mampu memadukan modernitas ke dalam sistem pendidikan pesantren dalam skala luar biasa kuatnya karena dukungan dari masyarkat. Tradisi pesantren sebagai penerus peradaban nusantara memiliki dasar pandangan keagamaan yang mudah dipadukan dengan modernitas. Cepatnya aspek modernitas terpadu dalam tradisi pesantren dapat dilihat dengan adanya kenyataannya sekitar 70 persen pesantren telah mengembangkan sekolahan dan sebagian mendirikan perguruan tinggi. Pesantren yang masih mengkhususkan pendidikan agama dan pengajian kitab-kitab Iskalm klasik sekitar 30 persen. ${ }^{14}$ Pada dasarwarsa ini tentunya jumlah dan prosentasi di atas sudah berubah seiring dengan berkembangnya jumlah pesantren.

Kondisi pesantren dengan perubahan yang sangat besar ini menunjukan bahwa pesantren mau berbenah dan melakukan inovasi untuk menghadapi percepatan perubahan zaman. menurut Zamahsyari Dofier mudahnya pesantren dalam perubahan inovasi pendidikan disebabkan beberapa hal yaitu: pertama, Bertambahnya jumlah pesantren menjadikan pesantren menjadi lebih leluasa melakukan variasi, dari yang paling kuat bertumpu kepada tradisi sampai kepada yang dapat memadu modernitas pendidikan seluas dan setinggi mungkin. Kedua, Sikap kyai yang semakin lapang dalam penyelenggaraan modernisasi pesantren di tengah-tengah perubahan masyarakat yang sangat cepat. Mereka tidak dihambat oleh pro atau kontra untuk mempertahankan aspek-aspek positif sistem pendidikan Islam. Tekanan telah mengarah kepada upaya menyantuni kebutuhan yang bermanfaat bagi umat islam. Ketiga, Keyakinan bahwa perubahan-perubahan harus diselenggarakan tanpa merusak

${ }^{14}$ Zamakhsyari Dofier, Tradisi Pesantren....,278 
aspek-aspek positif kehidupan pedesaan dimungkinkan oleh perkembangan teknologi serta semakin tersedianya sumber-sumber daya pendidikan melalui iternet. Keempat, Semakin tersedianya tenaga-tenaga akademik untuk pengembangan pendidikan tinggi di wilayah pedesaan. Kelima, Pengaruh kepemimpinan dan dukungan masyarakat menguat pada periode memasuki millenium ketiga. Keenam, Semakin kuatnyanya tuntutan masyarakat pedesaan untuk memperoleh haknya dalam memperoleh fasilitas pendidikan tinggi. Ketujuh, Tuntutan pelaksanaan demokrasi yang adil, jujur dan transparan semakin kuat. ${ }^{15}$

Di samping faktor-faktor di atas, format pesantren dengan sistem asramanya dianggap sebagai salah satu faktor yang menjadikan pesantren kian digandrungi masyarkat. Hal ini terbukti jumlah santri di pesantren kian hari kian menunjukan penambahan kuantitas yang signifikan. Masyarakt percaya bahwa dengan sistem ini, santri tidak sekedar mampu mengembangkan kecerdasan spritual dan intelektualnya. Tetapi sistem yang berlangsung secara berkesinambungan yang berlangsung secara kontinyu setiap hari mulai sejak bangun tidur di pagi hinggu menjelang tidur di malang hari, dapat membentuk krakter yang kuat. Makanya tidak heran santri memiliki ciri khas yang kuat dengan kemandiriannya dan karakternya, sehingga mereka mampu berkiprah di masyarakat.

Namun demikian tantangan yang akan dihadapi pesantren ke depan juga akan semakin meningkat searah dengan meningkatnya dampak arus global dalam kehidupan manusia. Untuk itu pesantren mau tidak mau harus mampu melahirkan santri yang mampu menghadapi gemuruh globalisasi tersebut.

Menurut Muhamad Nurdin pesantren perlu merespon dinamika zaman yang terus melaju dengan dengan melakukan inovasi format pesantren dengan tidak menghilangkan identitas dan ciri khas pesantren sebagai institusi pendidikan Islam yang bernuansi religius. Setidaknya ada tiga hal yang harus dilakukan pesantren yang peka zaman. pertama, pengembangan kurikulum pesantren. Dalam kurikulum tersebut pesantren tidak hanya bergelut dengan kitab kuningan semata, tetapi juga mengajarkan ilmu yang dibutuhkan oleh masyarakat, supaya bisa berdaya saing.

Kedua, manajemen pengelola. Para pengelola tidak berdasarkan kekeluargaan semata, tapi dipilih sesuai dengan kualitas keilmuan. Pengelola dilakukan perperiodik, bisa tiga tahun atau lima tahun sekali dipilih oleh dewan pesantren. Tujuannya untuk mengevaluasi dan menilai efektivitas kebijaksanaan pesantren, program, pelaksanaannya serta mutu lulusannya. Diharapkan juga dapat menganalisis kelemahan-kelemahan, kekuatan-kekuatan dan prestasi

${ }^{15}$ Zamakhsyari Dofier, Tradisi Pesantren..., 277-278 
Fauzan, Urgensi Kurikulum Integrasi di Pondok Pesantren dalam Membentuk Manusia Berkualitas

pesantren serta memberikan rekomendasi untuk menyususn rencana strategis terhadap pengembangan pesantren pada masa yang akan datang.

Ketiga, kepemimpinan pesantren. Dalam menggapai keberhasilan pesantren peka zaman, dibutuhkan sosok pemimpin yang handal. Sehingga memiliki peran dan fungsi yang sangat potensial untuk menggerakan, menata, dan mengelola pesantren bersama para kiai atau ustadz yang lainnya, dengan asas saling bekerja sama dan saling bahu membahu untuk memanjukan pesantren. ${ }^{16}$

Inovasi pesantren dapat dilakukan dengan melakukan pembaharuan pada sektor kurikulumnya. Kurikulum pesantren setidaknya harus dapat memenuhi tuntutan kebutuhan santri dan masyarakat agar menghasilkan out put yang handal dan siap berkompetisi di tengah-tengah masyarakat. Menurut M Sulthon untuk memenuhi tuntutan kebutuhan santri dan masyarakat, perlu dilakukan pembaharuan kurikulum pada tiga aspek yaitu; perencanaan, pelaksanaan dan evaluasi. Perencanaan kurikulum pesantren harus didahului dengan kegiatan kajian kebutuhan (need assessment ) secara akurat agar pendidikan pesantren menjadi lembaga yang tetap eksis dan mampu berperan pada era modern. Kajian kebutuhan tersebut perlu dikaitkan dengan tuntutan masa kini, utamanya kurikulum pendidikan yang berbasis kecakapan hidup ( life skills ) yang telah menjadi persoalan mendasar bagi para santri. ${ }^{17}$

Kurikulum berbasis kecakapan hidup (life skills ) adalah kurikulum yang mampu membekali kecakapan hidup para santri agar dapat memecahkan masalah -masalah dalam kehidupan. Dalam kehidupanya kelak, para santri tidak hanya memerlukan kemampuan teori teori semata, tetapi juga memerlukan kemampuan praktik. Artinya ada keseimbangan antara kemampuan teori dan praktik di lapangan agar pemenuhan kebutuhan para santri terhadap kecakapan hidup di berbagai bidang dapat terpenuhi. ${ }^{18}$

Salah satu bentu penerapan penerapan kurikulum berbasis kecakapan hidup yaitu dengan membekali santri dengan kemampuan praktik yang menjadi bekal ketika mereka kembali ke masyarakat. Untuk itu kurikulum pesantren dapat dikembangkan dengan membekali santri dengan pendidikan keterampilan melalui pelatihan-pelatihan yang mengarah kepada kebutuhan masyarakat. Pelatihan-pelatihan itu misalnya praktik pertanian,

\footnotetext{
16 Muhamad Nurdin, “Menggagas Pesantren Masa Depan”, dalam http:// www.nu.or.id /post/read/ 72432/ menggagas-pesantren-masa-depan (25 September 2017)

${ }^{17}$ M. Sulthon Masyhud, dkk. Manajemen Pondok Pesantren.., 72

${ }^{18}$ Suparlan, Tanya Jawab Pengembangan Kurikulum dan Materi Pembelajaran, (Jakarta: Bumi Aksara, 2011), 107.
} 
pengembangan ekonomi, elektronik, montir, industri rumah tangga, usaha produktif, dan semacamnya.

\section{Penutup}

Derasnya arus modernitas dan golabalisasi menuntut pesantren untuk melakukan inovasi. Inovasi itu dimaksudkan untuk melahirkan out put santri yang kompeten dan siap menghadapi kerasnya persaingan hidup. Inovasi pesantren dapat dilakukan dalam tiga sektor yaitu pengembangan kurikulum, manejemen pengelolaan, dan kepemimpinan pesantren.

Pengembangan kurikulum pesantren dapat dilakukan dengan mengintegarasikan kurikulum umum dan kurikulum pesantren. Kurikulum umum dapat dilakukan dengan mendirikan pendidikan formal dari tingkat sekolah dasar, sekolah menengah, hingga perguruan tinggi. Kurikulum pesantren tetap dipertahakan sebagai ciri khasnya yang tidak dapat dihilangkan dimana lulusan pesantren menuntut outputnya memiliki kemampuan agama.

Kurikulum pesantren juga dapat dikembangkan dengan mengembangkan kurikulum berbasis kecakapan (life skills). Kuirikulum ini dilakukan dengan membekali santri dengan kecakapan hidup agar mereka dapat memecahkan masalah-masalah dalam kehidupan nyata di masyarkat. Untuk itu, pesantren perlu mengembangkan program-progmram berbasis life skill dengan menyelenggarkan pelatihan-pelatihan keahlian tertentu. Dengan bekal keterampilan itu, santri dapat bersaing di saat mereka kembali ke masyarakat. 
Fauzan, Urgensi Kurikulum Integrasi di Pondok Pesantren dalam Membentuk Manusia Berkualitas

\section{DAFTAR PUSTAKA}

Departemen Agama RI-Direktorat Jenderal Kelembagaan Agama Islam, Pondok Pesantren dan Madrasah Diniyah: Pertumbuhan dan Perkembangannya, (Jakarta: Depag RI, 2003)

Fauzan, Peran Pesantren dalam Mengembangkan Pendidikan Karakter, Elfurqonia-Jurnal Ushuluddin dan Ilmu Keislaman STIU Al-Mujtma' Pamekasan Volume 01, Nomor 01. Agustus 2015

Hariyanto dan Minhaji, “Total Quality Management Berbasis Pesantren (Kajian Perspektif Pengelolaan Pendidikan Pesantren)", Jurnal Fikrouna, Volume 4, Nomor 2. Desember, 2016

Langgulung, Hasan. 1986. Manusia dan Pendidikan, Jakarta: Pustaka Al-Husna

Arifin, Imron. 1993. Kepemimpinan Kyai: Kasus Pondok Pesantren Tebuireng, Malang (Kalimasahada Press:)

Afiful Hair, Moh. Manajemen Pembaharuan Pesantren di Tengah Tantangan Kehidupan Masarakat Global, Jurnal Fikrotuna, Volume 4, Nomor 2 Desember, 2016

Mahfud, Moh. dan Hairit, Artamin "Pondok Pesantren Masa Depan (Studi Pola Manajemen PP. Nahdlatun Nasyiin Bungbaruh Kadur Pamekasan)”, Jurnal Fikrotuna, Volume 4., Nomor 2 Desember, 2016

Masyhud, M. Sulthon dkk. 2004 Manajemen Pondok Pesantren, Jakarta: Diva Pustaka, Cet. II,

Nurdin, Muhamad "Menggagas Pesantren Masa Depan", dalam http://www.nu.or.id/post/read/72432/menggagas-pesantren-masa-depan $(25$ September 2017)

Mulyasa. E, 2002. Manajemen Berbasis Sekolah- Konsep, Strategi, dan Implementasi, Bandung PT Remaja Rosda Karya

Qomar, Mujammil. 2005. Pesantren: dari Transformasi Metodologi menuju Demokratisasi Institusi. Jakarta: Erlangga,

Sulthon M. dan Khusnuridlo, Moh. Manajemen Pondok Pesantren dalam Perspektif Global, Yogyakarta (LaksBang PRESSindo:2006)

Pusat Bahasa Al-Azhar, "Life Skill untuk Meningkatkan Mutu Pendidikan Pesantren Sebagai Bagian dari Usaha Pengembangan Sumber Daya Manusia di Kabupaten Bangkalan, dalam https://pusatbahasaalazhar.wordpress.com. 15 September 2017 
FIKROTUNA: Jurnal Pendidikan dan Manajemen Islam Volume 6, Nomor 2, Desember 2017

Suparlan, 2011. Tanya Jawab Pengembangan Kurikulum Dan Materi Pembelajaran,Jakarta: Bumi Aksara.

Tim Penulis Pustaka Sidogiri, 1431. Mengapa Saya Harus Mondok di Pesantren?, Pasuran:Pustaka Sidogiri

Dhofier, Zamakhsyari 2015. Tradisi Pesantren- Studi Pandangan Kyai dan visinya Mengenai Masa Depan Pesantren, Jakarta :LP3ES, 